\title{
KONSEP EKONOMI PADA MASA RASULULLAH SAW
}

Devita Ayu Fildayanti/90100118020

\section{Sistem Perekonomian Pada Masa Rasulullah SAW}

Awal mula terbangunnya perekonomian berawal dari kepemimpinan Rasulullah SAW pada periode Madinah meskipun konsepnya relatif sederhana tetapi beliau telah menunjukkan prinsip-prinsip yang mendasar bagi pengelolaan ekonomi. ${ }^{1}$ Praktik ekonomi pada masa Rasulullah dan Khulafaurrasyidin menunjukkan adanya peranan pasar yang besar. Rasulullah sangat menghargai harga yang dibentuk oleh pasar sebagai harga yang adil. ${ }^{2}$ Rasulullah SAW adalah pemimpin pertama yang memperkenalkan konsep baru di bidang keuangan negara di abad ke-7. Semua hasil penghimpunan kekayaan negara dikumpulkan terlebih dahulu kemudian dikeluarkan sesuai dengan kebutuhan negara. Tempat pusat pengumpulan dana disebut bai al mal yang pada masa Nabi Muhammad SAW terletak di Masjid Nabawi. ${ }^{3}$ Peran dan fungsi baitul mal sendiri bukan hanya sekedar mengumpulkan uang dan membagikannya kepada masyarakat yang membutuhkan, namun lebih kepada pengolahan tatanan yang menopang perekonomian sehingga tidak terjadi sesuatu hal yang tidak diinginkan. ${ }^{4}$ Pada masa Rasulullah SAW ini, baitul mal lebih mempunyai pengertian sebagai pihak (al-jihat) yang menangani setiap harta benda kaum muslimin, baik berupa pendapatan maupun pengeluaran. ${ }^{5}$

Sumber-sumber pendapatan negara berasal dari Kharaj, Zakat, Khums, Jizyah, dan penerimaan lainnya. Kharaj yaitu pajak terhadap tanah, yang penentuannya berdasarkan tingkat produktivitas tanah atau berdasar pada tiga hal yaitu karakteristik atau tingkat kesuburan tanah, jenis tanaman dan jenis irigasi.

\footnotetext{
${ }^{1}$ Ibnuddin, Pemikiran Ekonomi Islam Pada Masa Nabi Muhammad, Jurnal Pendidikan dan Studi Islam, Vol. 5 No. 1, 2019, hal. 51-61.

${ }^{2}$ Idris Parakkasi dan Kamiruddin, Analisis Harga dan Mekanisme Pasar dalam Perspektif Islam, Laa Maysir, Vol. 5 No.1, 2018, hal. 107-120.

${ }^{3}$ Agus Marimin, Baitul Maal Sebagai Lembaga Keuangan Islam dalam Memperlancar Aktivitas Perekonomian, Jurnal Akuntansi dan Pajak, Vol. 14 No. 02, 2014, hal.39-42.

${ }^{4}$ Khurun 'In Zahro dan Mohammad Ghazali, Peran Baitul Mal dalam Daulah Islam sebagai Sentral Perekonomian Negara, Al-Ashlah, Vol. 3 No. 1, 2019, hal.118-29.

5 Sumadi dan Muhammad Tho'in, Paradigma Konsep Teori Dan Praktek Baitul Mal Dalam Prespektif Sistem Ekonomi Islam, Jurnal Ilmiah Ekonomi Islam, Vol. 6 No. 02, 2020, hal.330-38.
} 
Zakat, dikumpulkan dalam bentuk uang tunai yang diambil dari hasil peternakan dan hasil pertanian. Khums, yaitu pajak proporsional yang diambil dari barang temuan dan barang tambang, besarannya sebanyak $20 \%$. Jizyah, yaitu pajak yang dibebankan kepada orang-orang non muslim sebagai pengganti layanan sosial ekonomi dan jaminan perlindungan keamanan dari negara lain. Penerimaan lainnya seperti kaffarah dan harta waris dari orang yang tidak menjadi ahli waris. ${ }^{6}$

\section{Kebijakan Ekonomi Pada Masa Rasulullah SAW}

\section{Kebijakan Moneter}

Salah satu penyebab terjadinya peredaran uang terlalu tinggi adalah terjadinya defisit anggaran yang ditutup dengan pinjaman. Pada awal pemerintahan islam, defisit anggaran jarang terjadi dan sistem pengolahan moneter diserahkan kepada baitul mal. Setiap harta yang menjadi hak kaum muslimin, sementara pemiliknya tidak jelas maka harta tersebut merupakan hal baitul mall. Apabila harta itu telah diambil, maka pengambilan tersebut harta tadi telah menjadi hak baitul mall, baik harta itu dimasukkan ke dalam kasnya ataupun tidak. Di dalam pengelolaan moneter awal pemerintahan islam, dana dialokasikan untuk penyebaran islam, pendidikan dan kebudayaan, pengembangan ilmu pengetahuan, pengembangan infrastruktur, dan penyediaan layanan kesejahteraan sosial. $^{7}$ (Hoirul Amri)

\section{Kebijakan Fiskal}

Pada masa Rasulullah SAW sisi penerimaan APBN terdiri atas kharaj, zakat, khums, jizyah, dan penerimaan lain-lain. Di sisi pengeluaran terdiri atas pengeluaran untuk kepentingan dakwah, pendidikan dan kebudayaan, ilmu pengetahuan dan teknologi, kesejahteraan sosial, dan belanja pegawai. Penerimaan zakat dan khums dihitung secara proporsional yang dalam persentase dan bukan ditentukan nilai nominalnya. Sistem zakat perniagaan tidak akan mempengaruhi harga dan jumlah penawaran karena zakat dihitung dari hasil usaha.

\footnotetext{
${ }^{6}$ Ibnuddin, Pemikiran Ekonomi Islam Pada Masa Nabi Muhammad, Jurnal Pendidikan dan Studi Islam, Vol. 5 No. 1, 2019, hal. 51-61.

${ }^{7}$ Hoirul Amri, Kebijakan Moneter pada Awal Pemerintahan Islam dalam Pembangunan Perekonomian (Studi Analisis pada Masa Rasulullah SAW dan Sahabat), Muqtashid, Vol. 1 No. 01, 2016, hal.9-24.
} 


\section{DAFTAR PUSTAKA}

Amri, Hoirul. 2016. Kebijakan Moneter pada Awal Pemerintahan Islam dalam Pembangunan Perekonomian (Studi Analisis pada Masa Rasulullah SAW dan Sahabat, Muqtashid, I(01):9-24.

Ibnuddin. 2019. Pemikiran Ekonomi Islam Pada Masa Nabi Muhammad. Jurnal Pendidikan dan Studi Islam, 5(1):51-61.

Marimin, Agus. 2014. Baitul Mall sebagai Lembaga Keuangan Islam dalam Memperlancar Aktivitas Perekonomian, Jurnal Akuntansi dan Pajak, 14(02):39-42.

Parakkasi, Idris dan Kamiruddin. 2018. Analisis Harga dan Mekanisme Pasar dalam Perspektif Islam. Laa Maysir, 5(1): 107-120.

Sumadi, Muhammad Tho'in. 2020. Paradigma Konsep Teori dan Praktik Baitul Mal dalam Perspektif Sistem Ekonomi Islam. Jurnal Ilmiah Ekonomi Islam, 6(02):330-38.

Zohro', Khurun In. 2019. Peran Baitul Mal dalam Daulah Islam sebagai Sentral Perekonomian Negara. Al-Ashlah, 3(1):118-29. 